Biologists who joined the recent Zaire River expedition brought back a finc collection of flora and fauna, even if at times they may have felt that the price was rather high. In spite of bothersome details such as malaria, amoebic dysentery, fearsome rapids and mysterious footprints, the report delivered by three members of the expedition to a meeting of the Linnean Society on October 16 indicated a mission largely successfully accomplished.

Conditions were considerably better for the scientists, soldiers and other experts who set out under the auspices of the Scientific Exploration Society, in October 1974, than they had been 100 years before for Sir Henry Stanley and his followers who traced the course of the Congo, as the 2,718-mile long river was then called. This time, as Major J. BlashfordSnell reported, there were no hostile war canoes to face, and the inflatable boats used by the expedition were more serviceable than Stanley's Lady Alice, which had to be carried overland whenever rapids were approached. Stanley had no scientists in his party, but this time there were 50 , with varied medical, anthropological, geological, zoological and botanical interests. The two latter groups were represented at the meeting by $\mathrm{K}$. A. Joysey (University of Cambridge) and $\mathrm{H}$. W. Woolhouse (University of Leeds), respectively.

Joysey and his colleague, A. Friday, were concerned particularly to look for specimens of the West African otter shrew (Potamogale velox), a large and vicious insectivore that lives in muddy water and is apparently active only at night. After a rendezvous with local pigmies, an ctter shrew was eventually found, but proved elusive. The natives later presented the specimen, freshly killed, to the two zoologists who quickly removed the blood needed for serotaxonomic studies. The body is now in the Museum of Zoology at Cambridge.

\section{Stanley rides again}

$$
\text { by Mary Lindley }
$$

Other aquatic animals proved less elusive, with local markets yielding a good catch of lung fish (Protopterus), elephant fish (various genera of the family Mormyridae) and paddle fish (Polypterus) needed for protein sequence studies of muscle aldolase. Throughout the four months of the expedition a party was also collecting fish-from the lakes, tributaries and headwaters-for the British Museum (Natural History). Other ichthyologically inclined members of the expedition collected parasites, bile salts (for an evolutionary study) or fossil specimens. But the entomologists acquired the largest collection. They took home 4,000 Lepidoptera, constituting 800 species, of which a proportion is considered to be un- described. Experts at the British Museum (Natural History) are now working on these specimens, some of which will eventually be returned to the Government of Zaire. In the tropical rainforest the canopy level turned out to contain the greatest diversity of insect life, which seems to be quite distinct from the insect flora on the ground.

Throughout their journey, the three botanists on the expedition collected seeds of woody legumes for biochemical analysis of unusual amino acids. In southern Zaire, plant and soil specimens were collected for a study of the distribution of plants in relation to copper outcrops and the zonation of the flora was found to reflect the changing concentration of copper in the soil. A few species were growing in unusually toxic concentrations, with some lichens surviving on $5 \%$ copper. The material collected will be used in the search for the physiological basis of copper tolerance.

Data for a study of growth and productivity of Papyrus, with the aim of investigating the feasibility of making use of Papyrus again, was collected from the Upemba swamp basin, where the British botanists found working conditions none too pleasant. Another botanical project was a study of the frequency and distribution of plants which have the C4 pathway of photosynthesis. The outcome of this study will be reported later.
Nature, in the press; Herzenberg and Cantor, unpublished; Cantor and Pierce, unpublished) suppressor cells have an Ly phenotype (Ly 2,3) different from that of helper cells (Ly 1). They also possibly carry histamine receptors (Eichmann et al., Eur. J. Immun., 5, $511 ; 1975$ ) and may be Ia positive (Hammerling and Black, Tenth Leucocyte Culture conference, 1975). (See Table 1.) The view that at least some $\mathrm{T}$ suppressor cells may exert their effect by interaction with $T$ helper cells rather than directly with B cells (Herzenberg and Cantor, unpublished) is supported by much previous data. This may well be a manifestation of helper and suppressor cells belonging to different subsets of $T$ cells having complementary cell surface structures for interaction.

Recent work on idiotypes has shown that an antigen-specific receptor on $\mathrm{T}$ cells involved in help for antibody production and on $T$ cells involved in anti-MHC (major histocompatibility complex) responses shares determinants with the immunoglobulin receptor for that antigen on B cells (Binz and
Wigzell, J. exp. Med., 142, 197; 1975; Eichmann and Rajewsky, Eur. J. Immun., in the press). If this receptor is not cytophilically acquired, this work has important implications concerning the nature of $T$ cell receptors and suggests at least shared expression of a $V$ region gene on both $T$ and $B$ cells, perhaps in association with an $\mathrm{H}$ region product (for example Taussig and Munro, Nature, 251, 63; 1974). The fact that the idiotypes of receptors are antigenic and can provoke immune responses (refs above, and Jerne, Harvey Lecture, 1975, in the press; Lee et al., Nature, 247, 55; 1974) also opens up the possibility that an immune response to one antigen, once initiated, can provoke another immune response which limits or enhances the first response. This anti-idiotype response may, in turn, give rise to an anti-anti-idiotype response, and so on. This network theory has found favour amongst theorists and the data now accumulating suggest that anti-idiotype responses can occur during an immune response - but there is no good evidence as yet for their having a normal regulatory role.

The MHC plays an important part in cell-cell interactions during the induction of a whole range of cellular and humoral immune responses. In mice the MHC (H-2) is a series of loci mapping in the IXth linkage group (chromosome 17). Several other possibly analogous loci also exist on this chromosome. Of these the $\mathrm{T} / \mathrm{t}$ region near the centromere has long fascinated developmental biologists because it governs a sequence of distinct steps in embryogenesis. These events are precisely defined by the recessivelethal $T / t$ alleles because each of them halts development at the very point where the functional allele would normally act. The prevailing supposition that morphogenetic processes of this kind must involve genetically programmed sensory devices of the sort implied by terms like "cell-cell recognition" is substantiated by the finding that the $\mathrm{T} / \mathrm{t}$ genetic system, and at least one functional allele $\left(+^{t 12}\right)$ determines a distinct antigen (F9) that is expressed selectively on cells in a particular phase of differentiation. There 